\title{
AN ANALYSIS OF CODE SWITCHING IN BILINGUAL SCHOOL INCOMMUNICATION BY NON-NATIVE SPEAKER ENGLISH TEACHER IN BALI
}

\author{
N.P.R. Zenitha \\ ${ }^{123}$ English Language Education, Post Graduate Program, Universitas Pendidikan Ganesha, Denpasar \\ e-mail: putuzenitha1@gmail.com,
}

This study aimed at investigating types of code-switching pattern used by non-native speaker English teacher and the reason to use the code-switching. This research was a descriptive qualitative research. There were 3 informant samples from non native speaker English speaker in a bilingual school in Bali. The data were collected by using observation and interview. During the observation, the language used by the teachers was recorded and then transcribed. This transcription was analysed, and the occurrence of code switching was tabulated and classified. The results showed that, 1) there is an indication of insertion and alternation which occurred by non native speaker English during communication and mostly in the form of simple imperative and instructional utterances, and 2) the reason to use the code switching is to introduce and build the habit of the students to use acceptable English in different situations.

\section{Keywords: Code-Switching Pattern, Bilingualism, English as International Language}

\section{INTRODUCTION}

Globalization is the thing which is already happened in modern era. Globalization makes world becomes one nation when all of the countries depend on each other and globalization affects all aspects of human life (Wienda, Markamah, Mahfud, 2014). According to Tirtarahardja and Sulo (2005), there are 4 aspects which become the main target of globalization such as IPTEK (IImu Pengetahuan dan Teknologi), economy, environment and education. In terms of environment, culture as a part which affects the environment is also changed because of the globalization, including language.

Language is a system of arbitrary vocal symbols by means of which a social group cooperates (Bloch \& Tager, 1942 as cited by Wicaksana, 2017). Sapir (1921) and Goldstein (2008) as cited by Wicaksana, 2017 also define language as a purely human, non-instinctive method of communication system by using sound or symbol to communicate ideas, emotions, and desires by means of voluntarily produced symbols. Besides as the communication system, language also has a rule as a media in transferring the idea, a literary expression vehicle, a social institution, a political controversy matter, and catalyst for national building (Restuaji, 2015 as cited in O'Grady, Dobrovolsky, and Katamba, 1997). It can be assumed that language is important in the society because of many functions of language. Without language, meaningful communication cannot be built because people do not know how to communicate, express their idea, feeling, or gain political status. Based on two definitions above, we know how important the language is. With the language, we are able to speak with the people, interact with other people and it leads us to be welcomed in the society. Because language is accepted in the society and we use language for our daily life, we can conclude that language is a part of the culture of the society.

Language becomes the most fundamental medium to communicate in social interaction for either oral or written communication. People use language to express their thoughts, feelings, experiences, and other communication needs. In language interaction, language use has an important correlation with factors around it (Supiani, 2016). She also said that people commonly used language in accordance with social structure and value system in society. It can $b$ seen from a phenomenon that people tend to speak differently from one to other people in different circumstances which influences by many factors such as age, gender, ethnics, and even in a larger context which is culture of each people differs from one to another.

According to Sapir as cited in Baydak et al. (2015), language is defined as how people think meanwhile culture is what community think and does. Language plays an important role Jurnal Pendidikan Bahasa Inggris Indonesia | 53 
in culture interaction because it is used to convey and maintain culture. The relationship of culture and language is deeply rooted in which a language is transmitted as part of culture and culture is transmitted largely through language. Therefore, language cannot be studied in isolation from culture.

Humboldt (1973) in Baydak et al. (2015) believes that language is the main exponent of the national culture which means that every language is the carrier of culture and identity of the people who speak this language

English in the modern era is now considered as an international language. It happens because of dominance of English language in every aspects of life, including education. In Indonesia, English is taught as a foreign language (EFL) which exists in the curriculum from elementary to senior high school in Indonesia. According to the Badan Standar Nasional Pendidikan (2006), the purpose of English in elementary school are: (1) to develop the competency to communicate in spoken and written form in order to achieve the level of information literacy; (2) to make the students aware of the importance of English to enhance the nation competitiveness in the global community; (3) to develop students understanding about the relationship between language and culture. As mentioned by Fariadian, Azizifar, \& Gowhary (2014) the main goals of English teaching and learning are to develop learners' basic communication abilities and their interest in learning English. In dealing with global competition, it is indeed a good human resource is required. It includes the ability to use English as the international language. In order to use English successfully and effectively, there are four language skills that need to be mastered, namely: listening, reading, speaking, and writing.

In terms of education, English language, especially the standard-English language begins to take a role as a part of curriculum (Clark, 2013). Munandar (2015) also stated that the role as an International language is supported with the power of English which has various social, economic, political implication and notes that there has been an emphasis to examine the role of language in family, work and society relationship, including shift in power and authority among adult ESL students. Munandar's study in 2015 showed that the link of English and learner's social mobility is strong. Because English plays an important role in social mobility, many people learn English for their occupational and social goals. English contribute to social mobility of its learners in a way that it open an opportunity to engage in global participation and access to better-paid jobs and gain higher status in their society. English language is not only used by foreigner as well as an international communicators. English has been used by many people in the world to communicate with each other. In line with this statement, Ramelan (1992 ) stated that English as an international language is used to communicate, to strengthen and to fasten relationship among all countries in the world. Therefore, English became one of the important subject that have been applied by Indonesian Government that must be passed by all the students in final examination (UN). In this case, Indonesian Government intended to educate Indonesian students to learn English as well as to use it to communicate with others. Students learning language is considered to be successful if they can communicate effectively by using their second or fereign language. Hadfiels (1999) said that speaking is a kind of bridge for learners between classroom and the world aoutside. Thus, to build the good bridge, the quality of speaking must be enhance by practicing speaking fluency not only in the classroom meanwhile outside of the classroom to get the real context, situation and sensation in comunicating second or foreign language (English).

Since English is known as international language (Ministry of Education of Ontario, 2008, p. 4), the governments in almost all countries include English as a subject lesson in school. English is put as a foreign language which is taught in all level of school, starting from kindergarten, elementary, junior high school, high school, until higher education, such as college and university. Learning English could make the people interact and communicate with other people around the world and it makes learning English as a bridge to open a new wider opportunity in working and also be a positive achievement for certain people in the world and Yhamkhamnuan (2011, p. 2) stated that by knowing English, it opens new opportunity of education and employment which lead to a better life in society and have great value in business, and can automatically gain a higher position.

Learning to communicate a foreign language, such as English, is a very complex process which involves the development of the four language skills, listening, speaking, writing and 
reading (Kaçauni, 2014, p. 1). It always happens for the students whose first language is not English, for instance in Indonesia. When students face the difficulties in learning, they will lose their motivation and interest in learning. The learning activity will no become conducive and effective since the students lose their concentration in learning.

Another fact which indicated the use of English around the world is the Swedish syllabus which emphasized that teaching should be as far as possible be conducted in English (Sara, 2016). It can be assumed that although the meaning of "as far as possible" is not really exclude Swedish language, it can be assumed that the dominance of English really reach the education and disempowered local culture. The same thing also happens in Colombia when the Colombian government establish "National Plan of Bilingualism 2004-2019" which emphasized on three actions. First, Spanish and the aboriginal language is used for ethnoeducation. Second, the model of teaching must be flexible in order to make education for human development. Third, communicative competence in English must be improved in the public and private schools and universities of the country.

As the result of the use of English as an international language, the term "bilingualism" arisen. According to Bukhory and Susanti (2016), bilingualism is the concept of using two languages in the society. Brezjanovic and Shogren (2002) also simply define bilingualism as the alternation of two or more languages. Tunaz (2016) stated that the bilingual development occurred because of the advantages of becoming bilingual rather than monolingual. Lee, Choi and Pascual's studi (2016) of bilingual Korean and Mexican immigrant children explained that bilingual children use two languages while engaging with imaginary role play with doll and toys, the children also quickly caught the language based on the interlocutors. The study suggested that the use of bilingualism can be occurred in a wider situation to make the children adapt to the surrounding and fully use their communicative competence. Some researchers have conducted the various aspect of bilingualism and one of them is codeswitching. Code switching becomes a valuable academic concern in the field of linguistics with the appearance of bilingual and multilingual community (Wang, 2014).

Code switching is part of sociolinguistics. People tend to switch the language based on social context. Humboldt as cited in Baydak et al. (2015) who stated that language is the main exponent of the culture because every language is the carrier of culture and identity of people who speak this language. Language can be seen as the identity of certain community. Based on Baydak et al. (2015), sociolinguistics is a study that is concerned with the relationship between language and the context in which it is used. Meanwhile the term cultural linguistics clearly indicates the interrelation between linguistic and cultural studies. The main object of cultural linguistics is the relationship, interaction and interpretation of culture and language.

Language can be understood better when it is used in certain context. In using language, people need to consider the two contexts namely situational context and cultural context. These two contexts were used for the first time by anthropologist, Malinowski. The beginning is associated with research among the natives of the Trobriand Islands (Ilić, 2004). The data were collected by listening to conversation and observing behavior of people in South Pacific and Trobiand Island. In analyzing the data, Malinowski found difficulties because it was difficult to study their language behavior. He enriched linguistics with the idea that language is a mode of action rather than a counter sign of thought because language is sometimes not used for conveying thought and exchanging information, but simply for maintaining social and personal rapport. Furthermore, language is not only learnt from its situational context but it should be learnt from its cultural context.

Further, the concept of Malinowski was adapted by Hymes (1967) which added some aspects in analyzing language based on its context. Dell Hymes is considered as the founder of the area known as Ethnography of Communication. As cited in Safnil (2010) he proposed "ethnography of speaking" as follows.

1) Setting/scene: this is where the activities are taking place and the overall scene in which they are a part.

2) Participants: the people who get involved in the roles they play, or the relationships they have with other participants.

3) End: goals of communication. 
4) Act sequence: how speech acts are organized

5) Key: the tone and manner in which something is said or written

6) Instruments: the linguistic code i.e. language, dialect, variety and channel i.e. speech or writing

7) Norms: norm or the standard socio-cultural rules of interaction and interpretation

8) Genre: type of event such as lecture, poem, letter

According to Hoffman (1991), code switching is the alternation of two languages or linguistics varieties with the same utterance or during the same conversation. Code switching also refers to the alternate use of two or more languages in an extended stretch of discourse, where the switch takes place at sentence or clause boundaries $(\mathrm{Li}, 2008)$. Code-switching exists in bilingual societies where people have the opportunity to use two or more languages to communicate (Johansson, 2013)

There are three kinds of code-switching pattern based on Muysken (2000) such as insertion (intra-sentential code switching), alternation (inter-sentential code switching) and congruent lexicalization. Insertion is the incorporation of lexical items of whole units from one language into a structure of another language (Moyer, 2002). It is also supported by Juliadnyana (2017) which explain insertion (intra-sentential code-switching) as a simple type of code switching which switch phrase including a single word and not change the base of the language. Alternation (inter-sentential code-switching) is the switching between structures from separate languages. Congruent lexicalisation is the code switching which occurred if the two languages shared similar grammatical patterns like English-Dutch, English-Spanish, etc.

Code-switching is part of interaction. Interaction is described as the process of communication; it involves acts, actions, or practices of two people or more to affect each other's experiences or intentions (Brown, 2001). Interaction occurs as long as people are communicating each other and giving action and receiving the reaction in one another anywhere and anytime, including in the classroom setting. Dagarin (2004: 128) argued that classroom interaction is "two way process between the participants in the language process, the teacher influences the learners. Furthermore, interaction in the classroom is categorized as the pedagogic interaction which means the interaction in the teaching and learning process.

According to Ulfah (2012) state, the classroom interaction includes all of the classroom events, both verbal interaction and non-verbal interaction. The verbal interaction takes place because of the teacher and students talk, while non-verbal interaction covers gestures or facial expression by the teacher and students when they communicate without using words. These two kinds of talk are important; they dominate the classroom events and influence students' foreign language acquisition. Students learn not only through comprehensible input but also their own output. But a good lesson is not one in which students do all or even most of the talking. Some lesson may be good if they are carefully structured in such away that students do a good deal of talking and at the same time get a lot of feedback from the teacher, both formally and informally. But this is by no means true for all lessons.

Basically, the sign of using code switching can be seen through speaking. There are many definitions of speaking that have been proposed by some experts in language learning. Brown (2001: 267) cites that when someone can speak a language it means that he can carry on a conversation reasonably competently. In addition, he states that the benchmark of successful acquisition of language is almost always the demonstration of an ability to accomplish pragmatic goals through an interactive discourse with other language speakers. Richards and Renandya (2002: 204) state that effective oral communication requires the ability to use the language appropriately in social interactions that involves not only verbal communication but also paralinguistic elements of speech such as pitch, stress, and intonation. Moreover, nonlinguistic elements such as gestures, body language, and expressions are needed in conveying messages directly without any accompanying speech. Brown (2007) adds that social contact in interactive language functions is a key importance and in which it is not what you say that counts but how you say it what you convey with body language, gestures, eye contact, physical distance and other nonverbal messages.

In relation to speaking, code switching also happenend because of the vocabulary variation. Vocabulary is a basic component which a person must have before using a language. Vocabulary is very important to be taught to the students before they learn 
grammar and other language aspects. It can be successful in learning language if they want to master the vocabulary. They are impossible to be successful without mastering the vocabulary. Richards and Renandya (2002, p.255) state that vocabulary is a basic component of learning a language and also contains how well they speak, listen, and understand a language. Meanwhile, according to Hornby (as cited in Alqahtani 2015), vocabulary is the total number of words in language; vocabulary is a list of words with their meanings. Here, vocabulary also delivers meaning in each word. Each word can have two meanings, and the learners should master vocabulary well. This is important because without mastering the vocabulary, the learners cannot deliver their meaning or message well.

According to Nunan (1991), the acquisition of an adequate vocabulary is essential for successful for second language use because, without an extensive vocabulary, learners will be unable to use the structure and function they may have learned for comprehensible communication. It means mastering vocabulary is an essential component of all uses of language; it helps students to communicate effectively or expressing students' ideas in English. Without an extensive vocabulary and strategies for acquiring new vocabulary, learners often achieve less than their potential and may encouraged from making use of language learning opportunities around them such as listening to the radio, native speaker, using language in different context, reading or watching television.

According to Tarigan (1994: 447), vocabulary is: (1) all words contained in one language; (2) word richness possessed by a speaker; (3) a word used in one area of science; and (4) a list of words compiled like dictionaries with brief and practical explanations. It means that vocabulary the total number of words in language which is used in particular subject, like book. Besides, it can be used to express the idea. Vocabulary becomes the first element that should be mastered by the English learners in order they can master English well.

Good vocabulary mastery can help students understand the conversation in English. The more vocabulary it has, the more easily to express the ideas both in oral or written. The vast mastery of vocabulary in learning English can help students in understanding the meaning of the word contained in the English language. Without the extensive of vocabulary, students cannot use the language structure and language functions properly and correctly. Based on the explanation above, it can be concluded that vocabulary is the basic component of language that should be master by the students in order they can express their idea and they can use the language structure and language function correctly. Besides, the students can also understand the meaning of the sentence which found in language, especially in learning English.

According to Ricards and Renandya (2002), vocabulary is a core component of language profiency and provides much of basis for how well learners speak, listen, and write. It means that the first things we have to learn to master the vocabulary, because with vocabulary learners can learn language skills easier and will be useful for the process of achieving language teaching objectives. In other word, vocabulary is the important subject in language learning if learner lack vocabulary will face a lot of problems. It can be concluded that vocabulary is more than one, but the definition from one reference to other is related. From those the writer summarized that vocabulary is the total number of words that maintains all information used by person in communication and it is important thing when learners study the language itself and the using of the language.

Several studies had been conducted to investigate the code switching as the aspect of becoming bilingual. Gulzar (2010) stated that code-switching as a strategy should be introduced for teaching English in the bilingual classroom discourse but keeping in view the level of the students which means that code switching is needed to enhance the students in becoming bilingual. Pollard (2002) in her study in a public elementary school in Evanston, Illinois and a group of five Spanish-speaking fifth graders within an immersion classroom in a Bloomington, Illinois public elementary school stated that students who are allowed to code switch in the classroom are better able to convey their knowledge of subject matter to their classmates and teachers. Hasan and Akhand study in 2015 explained that code switching and code mixing already becomes part of the society and higher rank of society give positive attitude toward code switching and code mixing as a sign of "modernization". Promnant and Tayjasanant' study in 2016 explained that code switching from English to Thai could benefit their classes, as it is one of the most effective strategies for helping their students obtain 
clear ideas on the subject matter. The teachers could see that their students were more secured and confident than when listening to English only. Code switching was not only easy for students, but also for the teachers because it could save time and make students feel more confident and comfortable in their learning. Besides that, using code switching could help students with lower performance to be able to follow the lessons better than using only English through the learning periods. Code-switching could reduce the students' stress and made feel free to speak English by switching to Thai words sometimes when they could not think of what to say.

Rahmawati \& Ertin Recently (2015) did a research on assessing students' performances on speaking since the cultural and subjective issues embedded in bringing awareness on how teachers construct their speaking assessment. The main focus of this paper is a way to design assessment for speaking suitable for the Indonesian context at a university level. The research stresses the criteria of effective assessment proposed by Brown and Abeywicrama which consists of a specific criterion, an appropriate task, a maximum output and practical and a reliable scoring procedure. It is recommended that teachers develop their speaking assessment which is appropriate and contextual.

Proefschrift in 2019 with the study entitled Development of Surinamese Javanese: Language contact and change in a multilingual context found that there were differences in morphology and syntax: Surinamese speakers use less prefixation and suffixation on the verb, and overtly express the subject more frequently. All of these changes were seen as manifestations of language contact, and they were related to the speaker variable of age. It was found that almost all of these manifestations are correlated, meaning that there is a new type of speaker arising. Similarly, Bailoor, Jhon \& Laxman (2015) explored the disfluencies in English Speaking among Young Adults in Indian context in an attempt to assess the common disfluencies observed in 18 to 20 year old Indian adults who use spoken English. The focus of the study was to evaluate a diverse range of disfluencies that occur with various settings namely general conversation, story narration and monologue tasks. In all, there were mainly five types of disfluencies that were observed in them- pauses, repetitions, interjections, revision and prolongations; which do not affect the speech considerably but are present since an increased planning time is required for the rapid flow of speech. The present study has demonstrated that the normal speakers in the age range 18-20 years demonstrate a large number of disfluencies, notably pauses, repetitions and other disfluencies such as interjections, revision etc.

In those studies the emphasis was on the use of language as well as the occurrences of code switching and code mixing in English classes in the context of EFL and ESL classes. In this study, code switching was studied in the context of EFL teaching and learning, in which the teachers were the native speakers of English. It is important to know how the native speaker teachers cope with the use of language as the medium of instruction. More specifically, this study attempts to describe the types of could switching that occurred during the in class instructional process.

\section{RESEARCH METHOD}

This study belonged to qualitative study, which according to Creswell (2012) refers to a holistic approach that involves discovery process. Qualitative research is also described as an unfolding model that occurs in a natural setting that enables the researcher to develop a level of detail from high involvement in the actual experiences. This study was conducted in one bilingual kindergarten in Bali. The participant was the English teacher which not belongs to native speaker. The researcher did observation and acted as an observer. Seken (2004: pp 114-115) stated that there are two kinds of observation. There are participant observation (PO) and non-participant observation (NO). Participant observation means that the researcher participated and was actively involved in the interaction from which data were collected. Non-participant observation means the researcher is not participate in interactive event, although the researcher was in location. In this state, what the researcher needs to do is listening and recording. In other word, the observation which used is the non-participant observation.

The researcher also did the interview with 3 non-native speaker English teachers in that 
bilingual kindergarten. There are some criterias for the 3 non-native speakers as informant. There are:

a. never move out from school in a long time. The length of staying will be determined based on the data from the administration in the school.

b. does not have physical abnormality in their speech tool.

c. capable in communicating by using Indonesian language and Balinese language.

d. have a time to do an interview (Marjohan, Suarnajaya, Seken and Budasi: 2015)

Besides that, the researcher did recording in the form of record and video to help in obtaining data. Miles and Huberman data analysis theory was employed which include data reduction, data display and conclusion drawing. In this study, the researcher needs to do a data reduction to get a selective data which is useful in this study. The activities in data reduction include selecting, simplifying, classifying, categorizing and coding data (Miles and Huberman, 1984 as cited by Seken, 2004). The data from the observation, video and record was transcribed first in written form and the data categorized based on the types of codeswitching. Any data which is irrelevant is ignored. Next, the data was displayed descriptively and later verified by relating with the previous research to answer the problem which led into conclusion. This is the diagram of data analysis:

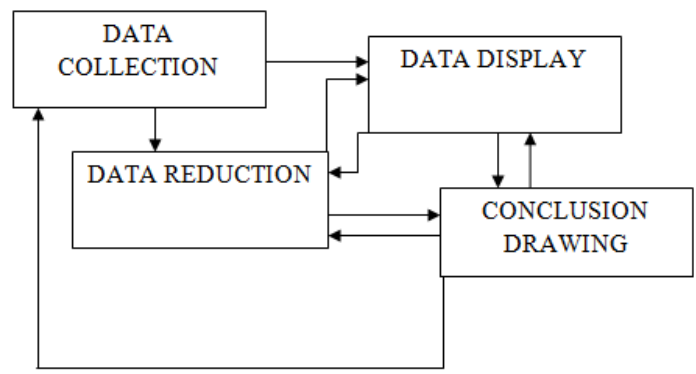

Picture 1. Miles and Huberman's Data Analysis Model

In order to maintain the trustworthiness of the data, the researcher needs to do data triangulation. According to Sugiyono (2012), there are three kinds of triangulation, there are triangulation of data collection technique, triangulation of source of data and triangulation of time. In this study, the researcher did data triangulation by using triangulation of data collection technique:

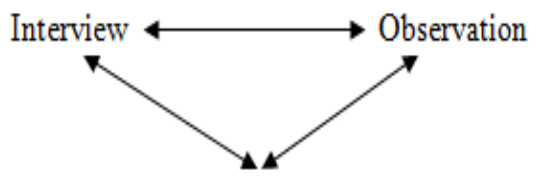

Questionnaire/Document

Picture 2. Sugiyono's Triangulation

Based on this diagram, the data which obtained by the $1^{\text {st }}$ instrument was related with the data from $2^{\text {nd }}$ instrument in order to maintain the validity of the data.

\section{FINDINGS AND DISCUSSION}

a. Insertion

Based on the data obtained by observation and recording, there were some utterances which indicated insertion, there were:

a) Allan, come (Allan, masuk)

\begin{tabular}{|l|l|}
\hline Indonesian Expression & CS \\
\hline Allan & Come \\
\hline
\end{tabular}


b) Put your shoes yang rapi

(Taruh sepatumu yang rapi)

\begin{tabular}{|l|l|}
\hline CS & Indonesian Expression \\
\hline Put your shoes & Yang rapi \\
\hline
\end{tabular}

c) No playing nanti nangis lagi (Tidak bermain nanti nangis lagi)

\begin{tabular}{|l|l|}
\hline $\mathbf{Z}$ & Indonesian Expression \\
\hline No Playing & Nanti nangis lagi \\
\hline
\end{tabular}

d) Sekarang dilihat sama teachersnya)

(Sekarang dilihat sama guru-gurunya)

\begin{tabular}{|l|l|l|}
\hline $\begin{array}{l}\text { Indonesian } \\
\text { Expression }\end{array}$ & CS & $\begin{array}{l}\text { Indonesian } \\
\text { Expression }\end{array}$ \\
\hline $\begin{array}{l}\text { Sekarang } \\
\text { dilihat sama }\end{array}$ & Teachers & Nya \\
\hline
\end{tabular}

e) Kalau masih not good nanti kamu watch aja (Kalau masih tidak bagus, nanti kamu nonton aja)

\begin{tabular}{|l|l|l|l|l|}
\hline $\begin{array}{l}\text { Indonesian } \\
\text { Expression }\end{array}$ & CS & $\begin{array}{l}\text { Indonesian } \\
\text { Expression }\end{array}$ & cS & $\begin{array}{l}\text { Indonesian } \\
\text { Expression }\end{array}$ \\
\hline Kalau masih & $\begin{array}{l}\text { Not } \\
\text { good }\end{array}$ & Nanti kamu & watch & Aja \\
\hline
\end{tabular}

f) Stop urusin teman (berhenti urusin teman)

\begin{tabular}{|l|l|}
\hline CS & Indonesian Expression \\
\hline Stop & Urusin teman \\
\hline
\end{tabular}

g) Kalau teman mau pentas please give applause (Kalau teman mau pentas mohon beri tepuk tangan)

\begin{tabular}{|l|l|}
\hline Indonesian Expression & CS \\
\hline Kalau teman mau pentas & please give applause \\
\hline
\end{tabular}

h) Ayo masuk teachernya mau datang (Ayo masuk, gurunya mau datang)

\begin{tabular}{|l|l|l|}
\hline $\begin{array}{l}\text { Indonesian } \\
\text { Expression }\end{array}$ & CS & $\begin{array}{l}\text { Indonesian } \\
\text { Expression }\end{array}$ \\
\hline Ayo masuk & Teachernya & Mau datang \\
\hline
\end{tabular}

i) Lihat gurunya explain (Lihat gurunya menjelaskan)

\begin{tabular}{|l|l|}
\hline Indonesia Expression & CS \\
\hline Lihat gurunya & Explain \\
\hline
\end{tabular}

Based on the data, it can be said that the insertion is dominantly happened by substituting one word or one simple phrase in the utterances and insertion as a part of codeswitching mostly happened in the form of imperative utterance. 
b. Alternation

There were also some utterances which indicated alternation, there were:

Diantar sama siapa? Your daddy?

(Diantar sama siapa? Ayahmu?)

\begin{tabular}{|l|l|}
\hline Utterance 1 & Utterance 2 (CS) \\
\hline Diantar sama siapa & Your Daddy? \\
\hline
\end{tabular}

Lalu sama siapa? Your mommy?

(Lalu sama siapa? Ibumu?)

\begin{tabular}{|l|l|}
\hline Utterance 1 & Utterance 2 (CS) \\
\hline Lalu sama siapa & Your Mommy? \\
\hline
\end{tabular}

Dari rumah ya adik. Udah breakfast?

Dari rumah ya adik. Udah makan pagi?

\begin{tabular}{|l|l|}
\hline Utterance 1 & Utterance 2 (CS) \\
\hline Dari rumah ya adik & Udah breakfast? \\
\hline
\end{tabular}

Stand up. Berdiri yang bagus

(Berdiri. Berdiri yang bagus)

\begin{tabular}{|l|l|}
\hline Utterance 1 (CS) & Utterance 2 \\
\hline Stand up & Berdiri yang bagus \\
\hline
\end{tabular}

Cari posisinya yang kemarin. Let's dance

(Cari posisinya yang kemarin. Ayo menari)

\begin{tabular}{|l|l|}
\hline Utterance 1 & Utterance 2 (CS) \\
\hline $\begin{array}{l}\text { Cari posisinya yang } \\
\text { kemarin }\end{array}$ & Let's dance \\
\hline
\end{tabular}

Wait. Sebentar ya

(Tunggu. Sebentar ya)

\begin{tabular}{|l|l|}
\hline Utterance 1 (CS) & Utterance 2 \\
\hline Wait & Sebentar ya \\
\hline
\end{tabular}

What do you like? Apple? Jeruk?

(Apa yang kamu suka? Apel? Jeruk?)

\begin{tabular}{|l|l|l|}
\hline $\begin{array}{l}\text { Utterance 1 } \\
\text { (CS) }\end{array}$ & $\begin{array}{l}\text { Utterance 2 } \\
\text { (CS) }\end{array}$ & Utterance 3 \\
\hline $\begin{array}{l}\text { What do you } \\
\text { like? }\end{array}$ & Apple? & Jeruk? \\
\hline
\end{tabular}

Based on the data, alternation was found in the form of simple utterances and it occurred as a repetition in terms of giving instruction to the students. Based on all obtained data, it can be said that insertion and alternation were occurred during communication between teacher and students in bilingual kindergarten and those types of code-switching mostly happened in the form of simple utterance in the form of instruction and imperative utterance. The reason why the teacher used code switching was in order to give students introduction about the use of English which lead the student to use English as a habitual communication in the school. The teacher's reason was supported by the one of the policies in that school which tells that "the graduated students are able to use English". This finding was similar with the previous studies from Tunaz in 2016 which explain the occurrence of insertion and alternation in 
multilingual child (Turkish/English/Arabic).

\section{CONCLUSION AND SUGGESTIONS}

Insertion and alteration were occurred in non native speaker English teacher during communication in bilingual kindergarten. The use of code switching by the teacher was happened in order to introduce the students the habit of using English in their daily life.

Based on the result of in this study, this study is expected as an evidence of the influence of English in Bilingual School and this is a good start to make English as a habit in school to keep the students to learn English.

\section{REFERENCES}

Alqahtani, M. (2015). The Importance of Vocabulary In Language Learning and How to be Taught. Vol. III, PP. 21-34

Bailoor, P., John, J., \& Laxman, J. (2015). Disfluencies in English Speaking Young Adults : A Supplementary Study in Indian Setup.

Baydak, A. V., Scharioth, C., \&ll'yashenko, I. A. (2015). Interaction of language and culture in the process of international education. Procedia - Social and Behavioral Sciences, 215, 14 - 18. doi: 10.1016/j.sbspro.2015.11.567

Brezjanovic, S. (2002). Analysis Of Code-Switching And Code-Mixing Among Bilingual Children: Two Case Studies Of Serbian-English Language Interaction. B. B. A., Wichita State University

Brown, H. D. (2001). Teaching by Principle: An Interactive Approach to Language pedagofy. New York: Addison Wesley longman, Inc

Bukhory, U and Susanti, F. (2016). The Difficulties Of Bilingualism (English And Arabic) On Speaking Ability Faced By The Members At The First Semester At Apk (Asrama Puteri Khadijah). Okara Journal of Languages and Literature, Vol. 1, Tahun 1, Mei 2016

Clark, U. 2013. A sense of place: Variation, linguistic hegemony and the teaching of literacy in English. English Teaching: Practice and Critique September, 2013, Volume 12, Number 2 pp. 58-75 ISSN 11758708

Creswell. 2012. Educational Research Planning, Conducting and Evaluating Quantitative and Qualitative Research. United States of America: PEARSON

Dagarin, M. 2004. Classroom interaction and Communication Strategies In Learning English As $A$ foreign. 1(1). Retrieved on August 21, 2017. Available at: http://www.sdas.edus.si/Elope/PDF/ElopeVollDagarinn.pdf

Fariadian, E., Azizifar, A., \&Gowhary, H. (2014). The Effect of anxiety on Iranian EFL learners speaking skill.International Research Journal of Applied and Basic Sciences, 8(10), 1747-1757.

Gulzar, M.A. 2010. Code-switching: Awareness about Its Utility in Bilingual Classrooms. Bulletin of Education and Research December 2010, Vol. 32, No. 2 pp. 23-44

Hadfield, Jill. 1996. Advanced Communication Games. England: Addison Wesley Longman Limited.

Hasan, M.K and Akhand, M.M. 2015. Reviewing the Challenges and Opportunities Presented by Code Switching and Mixing in Bangla. Journal of Education and Practice. ISSN 2222-1735 (Paper) ISSN 2222-288X (Online) Vol.6, No.1, 2015

Hoffman, C. 1991. An Introduction to Bilingualism. Second Edition. New York: Longman Press

Ilić, B. M. (2004). Language and culture studies - wonderland through the linguistic looking glass. Linguistics and Literature, 3(1), $1-15$.

Johansson, S. 2013. Code-Switching in the English Classroom: What teachers do and what their students wish they did. Karlstads University: Department of Language, Literature 


\section{and Intercultural Studies}

Juliadnyana, I.G. 2017. The Analysis of Teacher's Code Switching Based on The Perceptions of the Eight Grade Students of SMP Negeri 2 Sawan. Singaraja: Ganesha University of Education

Kaçauni, D. 2014. Teaching language skills to English young learners in Korça, Albania: Listening \& speaking. BJES Vol. 4 No. 1. Retrieved on February $2^{\text {nd }}, 2015$ from http://bjes.beder.edu.al/ uploads/arch-201405071114468325.pdf

Lee, J.S, Choi, J.Y and Pascual, L.M. 2016. An Analysis of Communicative Language Functions in the Korean and Mexican Immigrant Children. Vol. 5 No. 2. July 2016 pp. 66-73 ISSN: 2254-7339 DOI: 10.7821/near. 2016.7.193

Li, D.C.S. 2008. Understanding Mixed Code and Classroom Code-Switching: Myth or Realities. Hong Kong Institute of Education: New Horizons in Education, Vol. 56, No. 3, December 2008

Marjohan, Suarnajaya, Seken, Budasi. 2015. Pola Variasi Bahasa Bali: Kajian Sosiodialektologi Pada Masyarakat Tutur Di Bali Utara. Bali: Ganesha University of Education

Munandar, I. 2015. How Does English Language Learning Contribute to Social Mobility of Language Learners? Volume 22, Number 3, November, 2015, Page 236-242 doi:http://dx.doi.org/10.15548/jt.v22i3.157 Print ISSN 1410-7546 Online ISSN 23557893

Nunan, David. (1991). Language Teaching Methodology. New York: Prentice Hall.

Pollard, S. 2002. The Benefit of Code Switching within a Bilingual Education Program. Illinois Wesleyan University

Proefschrift. 2019. Development of Surinamese Javanese: Language contact and change in a multilingual context. Netherlands Graduate School of Linguistics

Promnant, K and Tayjasanant, C. English-Thai Code Switching of Teacher in ESP Classes. Kasetsart University. PASAA Vol. 51 January - June 2016

Ramelan. 1992. Introduction to Linguistic Analysis. Semarang: IKIP Semarang Press

Restuaji, N.A.R. 2015. Affixation Of Galungan Dialect: A Descriptive Study. Bali: Ganesha University of Education

Rianti. I. 2012. Landasan Pendidikan Nasional. AT-TA'LIM; Vol. 3, Tahun 2012

Ricards, J. C. And Renandya, W. A. (2002). Methodology in Language Teaching. New York: Cambrige University press, p. 255.

Safnil, A. (2010). Pengantar analisis retorika teks. Bengkulu: FKIPUNIB Press.

Sara, M. M. G. 2016. Review and Analysis of the Colombian Foreign Language Bilingualism Policies and Plans. http://dx.doi.org/10.19183/how.24.1.343

Seken, I. K. 2004. Being Polite in Balinese: An Analysis of Balinese Adat Leaders' Spoken Discourse. Malang: State University of Malang

Sugiyono. 2012. Metode Penelitian Kuantitatif, Kualitatif dan Kombinasi (Mixed Method). Bandung: ALFABETA

Tarigan, H.G. (1994). Menulis Sebagai Suatu Keterampilan Berbahasa, Bandung.

Tirtarahardja, Sulo. 2005. Pengantar Pendidikan (Edisi Revisi). Jakarta: PT Asdi Mahasatya

Tunaz. M. 2016. Development of Code-Switching: A Case Study on a Turkish/ English/Arabic Multilingual Child. Erciyes University

Ulfah, ulfah, s. s. 2015. AN ANALYSIS OF TEACHER AND. STUDENT TALK IN THE CLASSROOM INTERACTION OF THE EIGHTH GRADE OF SMPNEGERI 18 PURWOREJO. Vol 4 (2). Retrieved on November 10, 2017. Available: Jurnal Pendidikan Bahasa Inggris Indonesia | 63 
https://www.google.co.id/url?sa =t\&rct=i\&q=\&esrc=s\&source=web\&cd=7\&cad=rja\&uact= 8\&ved=0ahUKEwjWgqa08LjXAhUDK48KHXJ5Au8QFghiMAY\&url=http\%3A\%2F\%2Fjo urnal.walisongo.ac.id\%2Findex.php\%2Fvision\%2Farticle\%2Fdownload\%2F1594\%2F1 172\&usg=AOvVaw3FSKzBQkYS1XghBg6yBkIC

Wang, M. 2014. An Analysis on Code-Switching in Fortress Besieged from the Perspective of Register Theory. Canadian Center of Science and Education. English Language Teaching; Vol. 8, No. 1; 2015 ISSN 1916-4742 E-ISSN 1916-4750

Wicaksana, G.D.A. 2017. The Phonological and Lexical Variation of Lemukih and Galungan Dialect Viewed From Age Differences: An Analysis of Socio-Dialectology. Singaraja: Ganesha University of Education

Wienda, Markamah, Mahfud, 2014. Jurnal Didaktika Dwija Indria (SOLO) Vol 2, No 4. Solo: Jurnal Mahasiswa PGSD

Yiamkhamnuan, J. (2011). The mixing of Thai and English: Communicative strategies in internet chat rooms. Retrieved on December $18^{\text {th }}, 2014$ from http://www.trang.psu.ac.th/rtrang/images/stories/research/abstract/jirapron1 .pdf 